JURNAL TERKNOSAINS

VOLUME 2

No. 2, 22 Juni 2013

Halaman 71-158

\title{
HUBUNGAN ANTARA INDEKS VEGETASI NDVI (NORMALIZED DIFFERENCE VEGETATION INDEX) DAN KOEFISIEN RESESI BASEFLOW PADA BEBERAPA SUBDAS PROPINSI JAWA TENGAH DAN DAERAH ISTIMEWA YOGYAKARTA
}

\author{
Bokiraiya Latuamury \\ Program Studi Ilmu Lingkungan Sekolah Pascasarjana Universitas Gadjah Mada \\ Email: okky.environmentalscience@gmail.com \\ Totok Gunawan dan Slamet Suprayogi \\ Fakultas Geografi Universitas Gadjah Mada
}

\begin{abstract}
The background of this research is the decrease of environment capacity in cacthment ecosystem, especially impact of vegetation forest on behavior streamflow. The indicators of cacthment destruction can be seen through hydrograph characteristics. Evaluation of cactment respons of flow hydrographic as an evaluation tools of river catchment responses becomes very important to analyze because it is a benchmark in determination several policy about flood, drough, sedimentation and landslide handling. The research purpose is to analyze the relationship between vegetation index NDVI (Normalized Difference Vegetation Index) and the characteristic of baseflow recession coefficient at several subcatchment areas in province of Central Java and Specific District of Yogjakarta. The method of this research is surveillance on data recording of AWLR (Automatic Water Level Recorder) and data of River Flow Measuring Stations in order to separate the baseflow by calibration curve, and image interpretation of Landsat $E M^{+}$for the transformation of vegetation index (NDVI-Normalized Difference Vegetation Index). The analysis on recession coefficient data $(\mathrm{Kr} b)$ and NDVI were correlated to analyze the strength of relationship between these two parameters. The results of statistical analysis on index NDVI and recession coefficient shows that NDVI and recession coefficient value at $R^{2}$ is $0.1427, F=2.17$ which is not significant at $1 \%$ significance level of 0.1646 . The result shows a very weak correlation of 0.077 which mean that vegetation density (NDVI index) has a very weak control on low flows. Basically, river baseflow is a genetic component of river flow which comes from aquifer storage and/or other low flow sources. Thus, geology and soil have a significant effect on baseflow.
\end{abstract}

Keywords: NDVI (Normalized Difference Vegetation Index), Koefisien Resesi Baseflow, Hidrograf.

\begin{abstract}
ABSTRAK
Artikel ini dilatarbelakangi oleh penurunan daya dukung lingkungan dalam ekosistem DAS, terutama pengaruh perubahan vegetasi hutan terhadap perilaku aliran. Indikator kerusakan lingkungan DAS terhadap perilaku hidrologi dapat ditelusuri melalui karakteristik hidrograf. Evaluasi respon DAS dari hidrograf aliran menjadi sangat penting untuk dianalisis karena merupakan tolok ukur dalam penentuan kebijakan pengelolaan permasalahan lingkungan yakni banjir, kekeringan, sedimentasi dan tanah longsor. Tujuannya untuk menganalisis hubungan antara indeks vegetasi NDVI (Normalized
\end{abstract}


Difference Vegetation Index) dan koefisien resesi baseflow pada beberapa sub DAS di Propinsi Jawa Tengah dan Daerah Istimewa Yogyakarta. Metode survei digunakan dalam penelitian ini untuk memperoleh (1) rekaman data SPAS (Stasiun Pengamatan Aliran Sungai) dan AWLR (Automatic Water Level Recorder) dengan teknik pemisahan baseflow untuk memperoleh persamaan liku kalibrasi dan koefisien resesi, dan (2) interpretasi citra Landsat $\mathrm{ETM}^{+}$untuk transformasi indeks vegetasi NDVI. Hasil analisis korelasi antara indeks vegetasi NDVI dan koefisien resesi $(\mathrm{Krb})$ memperoleh nilai $\mathrm{R}^{2}=0,1427, \mathrm{~F}=2.17$ tidak berpengaruh nyata pada taraf signifikan $1 \%$ sebesar 0.1646 . Hasil ini menunjukkan bahwa indeks vegetasi NDVI sangat lemah mengontrol keberadaan aliran-aliran rendah terutama baseflow karena pada prinsipnya aliran dasar sungai merupakan komponen genetis aliran sungai yang berasal dari penyimpanan akuifer dan/atau sumber-sumber aliran lambat lainnya. Dengan demikian pengaruh tanah dan geologi berpengaruh sangat nyata terhadap aliran dasar.

Kata Kunci: NDVI (Normalized Difference Vegetation Index), Koefisien Resesi Baseflow, Hidrograf.

\section{PENGANTAR}

Pola produksi dan konsumsi yang agresif, eksploitatif, dan ekspansif terhadap sumberdaya alam vegetasi, tanah, dan air telah menurunkan daya dukung dan fungsi lingkungan daerah aliran sungai (DAS). Kerusakan ekosistem dalam tatanan DAS di Indonesia telah teridentifikasi dengan frekuensi kejadian bencana banjir, erosi, sedimentasi, dan tanah longsor yang semakin meningkat.

Ekosistem DAS dengan segala sumberdaya yang terdapat di dalamnya, mempunyai batas kemampuan untuk dapat mendukung kehidupan di dalamnya. Pemanfaatan sumberdaya alam yang melampuai daya dukung lingkungan akan menimbulkan banyak permasalahan lingkungan. Konsekuensi lingkungan akibat perubahan penutupan lahan bervegetasi, mencakup dampak sosial, ekonomi maupun ekologi perlu dipertimbangkan sebagai dampak besar dan penting dalam sejumlah Pengelolaan sumberdaya alam skala DAS.

Karakteristik hidrograf aliran sebagai tanggapan menyeluruh (integral response) terhadap masukan harus sesuai dengan sifat dan perilaku DAS yang bersangkutan. Hidrograf aliran dapat digunakan sebagai alat diagnosis atau penyidikan secara cepat terhadap dinamika respon aliran DAS secara spasial dan temporal. Kerusakan lahan pada DAS ditunjukkan dengan debit puncak yang semakin tinggi, waktu konsentrasi pendek dan runoff semakin besar (Sri-Harto, 2000). Pada saat tidak hujan, maka aliran sungai mendapat kontribusi dari air tanah yang teratuskan. Aliran ini disebut sebagai baseflow.

Baseflow merupakan salah satu karakteristik hidrologi aliran rendah yang paling penting dalam sistem DAS. Pengetahuan karakteristik baseflow penting untuk sejumlah pertimbangan, antara lain dalam pengembangan strategi pengelolaan air di kondisi kekeringan, estimasi pasokan air skala kecil sampai menengah, pengelolaan kualitas air, membangun hubungan antara hidrologi akuatik dan lingkungannya; dan perkembangbiakan tumbuhan perairan (Nathan,1990).

Berdasarkan uraian tersebut, maka penelitian ini dimaksudkan untuk menganalisis hubungan indeks vegetasi NDVI (Normalized Difference Vegetation Index) dan koefien resesi baseflow pada beberapa subDAS di Propinsi Jawa Tengah dan Daerah Istimewa Yogyakarta. Analisis ini bertujuan menganalisis indeks vegetasi NDVI (Normalized Difference Vegetation Index) sebagai refresentasi karakteristik kerapatan vegetasi pada ekosistem DAS; menganalisis koefisien resesi baseflow sebagai refresentasi karakteristik resesi baseflow di beberapa sub-DAS. Analisis untuk korelasi indeks vegetasi NDVI dan koefisien resesi baseflow pada beberapa sub DAS. 


\section{Karakteristik Hidrograf Aliran}

Hidrograf merupakan tanggapan menyeluruh (integral response) terhadap masukan tertentu sesuai dengan sifat dan perilaku DAS yang bersangkutan. Hidrograf aliran selalu berubah sesuai dengan besaran dan waktu terjadinya masukan (Sri-Harto, 1993). Hidrograf Aliran terdiri dari tiga bagian yaitu sisi naik (rising $\operatorname{limb}$ ), puncak (crest), dan sisi turun (recession $\operatorname{limb}$ ), sedangkan bentuk dari Hidrograf ditentukan oleh tiga besaran pokok sebagai berikut:

Pertama, waktunaik (time of rise, Tp) „yaitu waktu yang dihitung dari permulaan hujan sampai dengan waktu terjadinya debit maksimum. Hal yang berpengaruh terhadap waktu naik adalah kecepatan aliran/ limpasan langsung (direct runoff). Waktu naik sangat dipengaruhi oleh kecepatan aliran di lahan dan alur. Semakin cepat aliran baik di lahan maupun di alur sungai, maka waktu yang diperlukan untuk mencapai debit puncak akan semakin kecil, demikian pula sebaliknya.

Fungsi vegetasi hutan dalam mengatur lingkungan hidrologis adalah dengan perlindungannya terhadap tenaga kinetis air hujan, melalui tiga lapisan yakni bagian tajuk (canopy), batang, dan seresah hutan. Dengan adanya perubahan penutupan lahan hutan menjadi non-hutan berarti pohonpohon yang biasanya mampu menahan air hujan melalui dedaunan, ranting, dan batang hilang, sehingga air hujan yang jatuh akan lebih cepat sampai ke tanah. Perubahan penutupan lahan hutan juga menyebabkan hilangnya seresah hutan karena tidak ada lagi bagian-bagian vegetasi hutan yang terdapat di atas lahan. Tidak adanya pohon dan seresah berarti hambatan terhadap limpasan permukaan (surface runoff) menjadi lebih kecil dan air akan mengalir lebih cepat menuju alur sungai. Demikian halnnya akar-akar pohon dapat menggemburkan tanah, di mana pada tanah yang gembur pori-pori tanah lebih besar, terdapat banyak bahan organik dan organisme tanah, berakibat transmisivitas tanah makin tinggi, sehingga infiltrasi akan lebih besar dan limpasan langsung makin kecil. Dengan tidak adanya ketiga hal tersebut maka waktu yang diperlukan untuk mencapai debit puncak (peak discharge) pada suatu alur sungai menjadi semakin pendek.

Kedua, Debit puncak (peak discharge), yaitu debit maksimum yang dapat dicapai selama terjadi limpasan langsung. Besarnya limpasan langsung (direct runoff) dan kecepatan akumulasi debit, akan menentukan tingginya debit puncak. Apabila sebagian besar air hujan yang jatuh menjadi limpasan langsung dan sedikit sekali yang terinfiltrasi, maka akumulasi debit dalam suatu sungai akan semakin besar. Tidak adanya pohon dan seresah hutan akibat perubahan tutupan hutan menjadi non hutan, maka hambatan terhadap limpasan permukaan menjadi lebih kecil dan kecepatan aliran semakin besar, sehingga semakin kecil kesempatan air terinfiltrasi dan sebagian besar air hujan yang jatuh menjadi limpasan langsung.

Vegetasi hutan dapatmenjaga kesuburan tanah dan besarnya pori-pori tanah, karena adanya aktivitas mikroorganisme dan akarakar vegetasi tersebut. Dengan tidak adanya vegetasi hutan berarti tidak ada aktivitas mikroorganisme dan akar-akar vegetasi hutan sehingga tanah akan menjadi padat. Dengan semakin padatnya tanah tersebut, maka laju infiltrasi akan semakin kecil dan sebagian besar air hujan yang jatuh ke tanah akan menjadi limpasan langsung. Besarnya limpasan langsung ini mengakibatkan terjadinya akumulasi debit pada alur sungai sehingga menyebabkan debit puncak semakin besar.

Ketiga, waktu dasar(base time), yaitu waktu yang dihitung dari permulaan hujan sampai dengan berakhirnya limpasan langsung. Tingginya kecepatan aliran/limpasan langsung (direct runoff) sangat menentukan panjangnya waktu dasar. Semakin tinggi kecepatan aliran/limpasan langsung baik pada sisi naik maupun pada sisi resesi, maka waktu yang diperlukan terjadinya limpasan 
kangsung (waktu dasar) akan semakin pendek, demikian juga sebaliknya.

Kecepatan aliran/limpasan sangat tergantung pada kondisi permukaan lahan. Semakin kecil hambatan yang ada di permukaan lahan, maka kecepatan aliran akan semakin tinggi. Tidak adanya vegetasi hutan akibat perubahan tutupan lahan hutan menjadilahan non-hutan dapat menyebabkan hambatan di atas permukaan lahan menjadi semakin kecil, sehingga air hujan yang jatuh akan semakin cepat sampai ke tanah dan mengalir di atas permukaan tanah dengan kecepatan yang lebih tinggi. Semakin kecilnya hambatan di atas permukaan lahan, maka semakin pendek waktu yang diperlukan untuk mencapai debit puncak pada sisi naik dan semakin pendek pula waktu yang diperlukan untuk pengatusan pada sisi resesi. Dengan demikian total waktu dasar yang diperlukan untuk terjadinya limpasan langsung akan semakin pendek.

\section{Lengkung Resesi Aliran Dasar}

Metode pembuatan lengkung resesi merupakan kunci dari teliti atau tidaknya pembuatan hidrograf aliran. Hidrograf aliran adalah suatu grafik yang menunjukkan sifatsifat aliran sungai dalam suatu DAS, yang dinyatakan dalam grafik debit terhadap waktu. Hidrograf merupakan perwujudan dari pengaruh-pengaruh hidrometeorologis dan fisiografis suatu DAS (Viessman, 1989 dalam Sri-Harto 1993). Pada bagian resesi, setelah titik infleksi, aliran resesi dibagi menjadi beberapa unsur, channel storage, interflow, dan groundwater storage.

Channel storage merupakan pengatusan dari surface runoff, sedangkan interflow merupakan aliran antara, dan pada resesi bagian akhir adalah resesi baseflow yang merupakan pengatusan aliran airtanah (Wilson, 1989 dalam dalam Sri-Harto 1993). Apabila tidak terjadi hujan untuk jangka waktu yang panjang, maka slope dari hidrograf yang terbentuk merupakan perwujudan dari aliran airtanah yang disebut dengan baseflow. Lengkung resesi baseflow dapat digunakan untuk analisis keadaan pengatusan timbunan air dalam suatu DAS. Banyak aplikasi praktis yang mendasarkan pada sifat-sifat lengkung resesi baseflow antara lain adalah peramalan aliran rendah atau aliran minuman, pengawasan irigasi airtanah selama periode aliran rendah, estimasi dan prakiraan suplai airtanah, analisis kemampuan dan kapasitas maksimum akuifer dan sebagainya (Singh, 1987 dalam dalam Sri-Harto 1993).

Lengkung resesi aliran dasar untuk suatu daerah aliran sungai selalu sama (Subarkah, 1980 dalam Saparis, 1997). Lengkung resesi dapat dinyatakan dalam suatu persamaan umum yang berlaku untuk semua hujan di dalam DAS. Persamaan umum ini dinyatakan dalam fungsi Qt terhadap Qo dan $t$ atau Qt $=$ Qo $(f(t))$, di mana $f(t)$ merupakan fungsi eksponen. Untuk selanjutnya aliran airtanah ini disebut dengan aliran dasar dan kurva aliran dasar disebut dengan lengkung resesi aliran dasar atau lengkung resesi baseflow.

\section{Koefisien Resesi Aliran Dasar}

Hidrograf aliran pada bagian resesinya terdiri dari beberapa komponen, di mana masing-masing komponen air tersebut berasal dari media yang berbeda sehingga sifat pelepasan alirannya berbeda. Pelepasan air yang paling cepat berasal dari surface detention storage, kecepatan sedang berasal dari interflow dan pelepasan air dengan kecepatan paling lambat dari groundwater storage. Dengan mempertimbangkan perbedaan pelepasan aliran tersebut, maka dimungkinkan melakukan pemisahan komponen aliran dari masing-masing sumber. Faktor yang membedakan kecepatan pelepasan aliran dalam suatu persamaan lengkung resesi baseflow biasanya dinyatakan dalam koefisien resesi (K). Dalam penelitian ini, yang akan dicari adalah koefisien resesi baseflow $\left(\mathrm{K}_{\mathrm{rb}}\right)$. 
Nilai $\mathrm{K}_{\mathrm{rb}}$ ditentukan dengan menggambarkan nilai-nilai Qo terhadap Qt dengan selang waktu $t$ satu hari. Nilai Qo dan Qt diambil dari sembarang kurva resesi aliran dasar pada hidrograf aliran, di mana pada penyebaran titik-titik hasil plot dari nilai Qo dan Qt, kemudian dibuat regresi linier dengan fungsi sebagai berikut:

$$
\begin{aligned}
& \mathrm{Q} \mathrm{t}=\mathrm{K}_{\mathrm{rb}} \mathrm{Qo} \\
& K_{r b}=\frac{Q_{t}}{Q_{0}}
\end{aligned}
$$

di mana $K_{\mathrm{rb}}$ (koefisien resesi baseflow) merupakan gradient dari garis regresi ini.

Metode lengkung aliran yang baik untuk suatu DAS adalah metode lengkung aliran yang digunakan dengan pendekatan regresi yang harus diuji terlebih dahulu tingkat penyimpangannya. Garis lengkung yang terbentuk tergantung dari sebaran titik data yang ada. Sebaran titik-titik data tersebut dipengaruhi oleh bentuk penampang saluran.

\section{Hubungan Transformasi Indeks Vegetasi dengan Kerapatan Tajuk Vegetasi}

Beberapa penelitian terdahulu menjelaskan bahwa dengan melakukan transformasi indeks vegetasi, maka kerapatan vegetasi atau aspek-aspek yang berkaitan dengan kerapatan seperti indeks luas daun, konsentrasi klorofil, dan lainlain dapat ditonjolkan (Danoedoro, 1996). Selanjutnya Mather (1987 dalam Danoedoro, 1996) menjelaskan bahwa dengan melakukan rasio antara saluran inframerah dekat dengan saluran merah, mampu mengurangi efek bayangan akibat perbedaan penerimaan tenaga matahari. Hasil penelitian menjelaskan bahwa indeks vegetasi NDVI dari analisis citra Landsat $\mathrm{ETM}^{+}$berkorelasi signifikan dengan kerapatan tajuk pada umur tanaman tertentu.

Kerapatan tajuk tanaman di lapangan berbanding terbalik dengan kerapatan tumbuhan bawah, artinya pada lokasi di mana ditemukan kerapatan tajuk yang cukup tinggi, maka kerapatan tumbuhan bawah bervariasi dari jarang sampai sedang. Demikian juga sebaliknya apabila ditemukan kerapatan tajuk tanaman yang jarang, maka kerapatan tumbuhan bawah cukup tinggi. Kondisi ini akan menyebabkan efek distribusi yang sempit pada nilai spektral, di mana pada tingkat kerapatan tajuk yang berbeda, maka nilai piksel dapat memberikan efek pantulan yang sama. Akan tetapi, Howard (1991), menjelaskan bahwa pada kondisi kerapatan tajuk yang demikian, walaupun indeks luas daunnya sama, tetapi pantulan yang besar akan terjadi pada kedudukan tinggi tajuk yang relatif sama. Sedangkan pada kedudukan tinggi tajuk yang relatif berbeda, maka pantulannya akan berkurang, hal tersebut disebabkan oleh bayangan tajuk pertama terhadap tajuk berikutnya, sehingga akan mengurangi energi radian yang terekam oleh sensor.

Vegetasi dengan kondisi tajuk yang rapat akan meningkatkan variasi nilai indeks luas daun, sehingga variasi pada nilai pantulan spektral pada kerapatan tajuk yang sama disebabkan oleh perbedaan pada indeks luas daunnya, dan hal tersebut akan memberikan kesalahan didalam menduga tingkat kerapatan tajuk (Purevdorj dkk., 1998). Dengan demikian jelas bahwa dalam melakukan transformasi NDVI, maka aspek kerapatan dapat ditonjolkan. Akan tetapi, dari beberapa faktor lain yang mempengaruhi nilai spektral selain kerapatan tajuk nampaknya agak sulit untuk diidentifikasi. Jika dibuat suatu asumsi berdasarkan beberapa penelitian terdahulu, kemudian dikaitkan dengan hasil penelitian sekarang mengatakan bahwa 55-60\% tingkat kerapatan tajuk tanaman dapat dijelaskan dengan nilai spektral, maka $40-45 \%$ sisanya merupakan pengaruh faktor lain. Faktor lain ini bisa berupa perbedaan kandungan klorofil, perbedaan umur daun, perbedaan kadar air dalam daun, faktor kerusakan 
daun, latar belakang tanah, pengaruh bayangan terutama akibat perbedaan lereng, dan aspek lereng. Dengan demikian jelas bahwa penggunaan transformasi indeks vegetasi cukup efektif untuk menduga tingkat kerapatan tajuk vegetasi.

Kajian hidrologi, penutupan lahan bervegetasi mempengaruhi proses pembentukkan aliran di suatu DAS. Hal ini terutama dikaitkan dengan proses intersepsi oleh tajuk vegetasi, yang secara efektif dapat menghambat air hujan untuk sampai ke permukaan tanah. Banyak penelitian menunjukkan bahwa vegetasi yang rapat dapat memperkecil aliran permukaan namun meningkatkan kapasitas infiltrasi tanah, sehingga tampungan airtanah meningkat.

Pada Siklus hidrologi, hujan terjadi dari penguapan air terutama air dari permukaan laut yang naik ke atmosfer kemudian mengalami kondensasi dan turun sebagai hujan. Air hujan yang jatuh pada suatu DAS sebelum menjadi aliran langsung terlebih dahulu mengalami perjalanan melalui beberapa tingkat penimbunan dan pemindahan. Pada mulanya air hujan jatuh di atas vegetasi, batuan, permukaan tanah, dan saluran-saluran sungai. Hujan yang jatuh di permukaan vegetasi mengalami intersepsi. Sebagian jatuh ke tanah melalui sela-sela daun atau dari tetesan daun, ranting dan cabang. Air hujan yang mencapai permukaan tanah mengalami infiltrasi dan mengisi ledok-ledokan yang ada sebagai timbunan depresi. Setelah mencapai kapasitas infiltrasi, maka air hujan ini akan menjadi aliran pada permukaan tanah. Sedangkan air yang terinfiltrasi akan mengalami lengas tanah dan airtanah. Dengan demikian kerapatan vegetasi memiliki pengaruh terhadap aliran dalam sistem DAS.

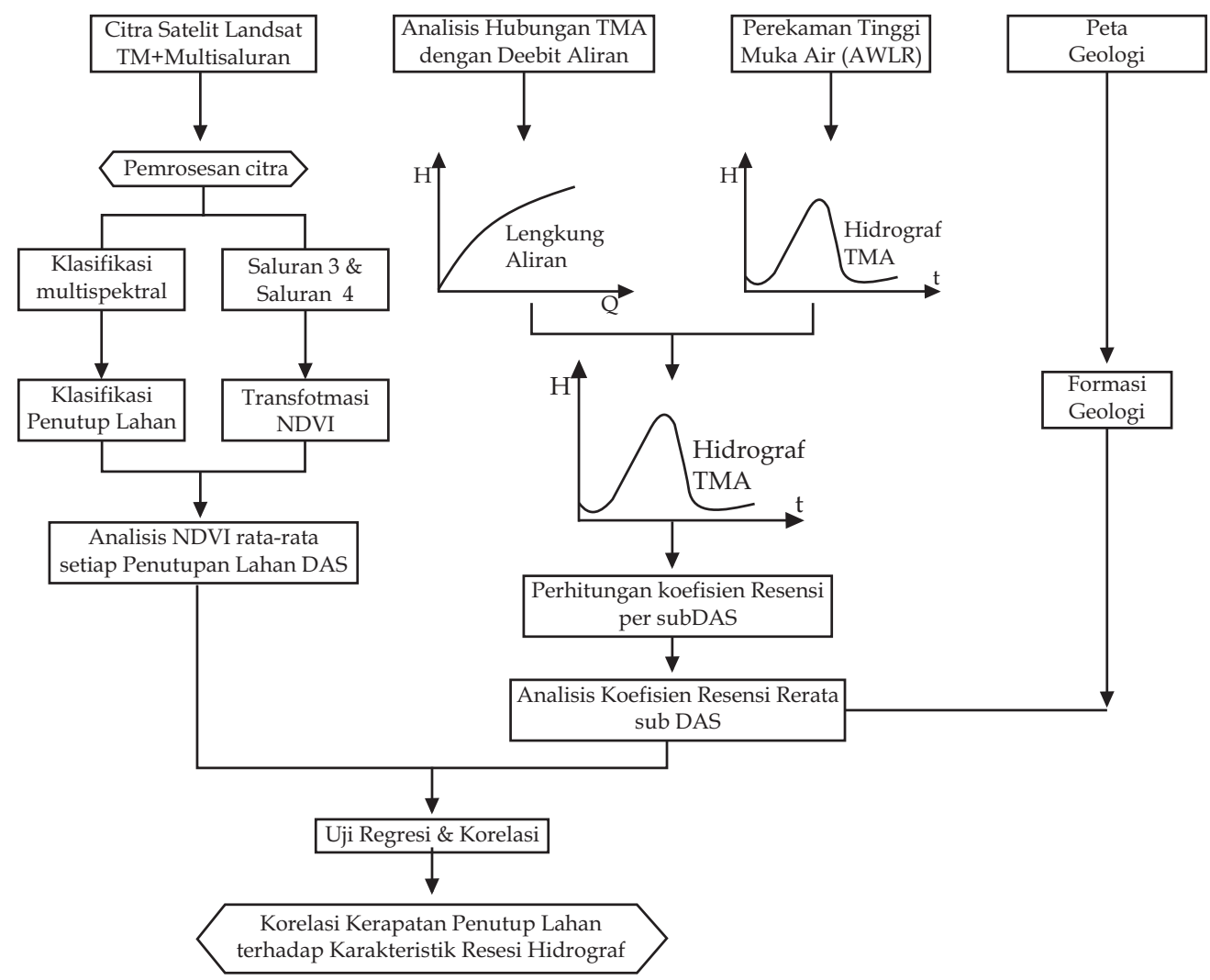

Gambar 1. Kerangka Pemikiran Penelitian 
Daerah penelitian meliputi 15 sub-DAS di propinsi Jawa Tengah dan Propinsi DIY, didasarkan atas ketersediaan Stasiun Pengamatan Aliran Sungai (SPAS) dan AWLR (Automatic Water Level Recorder). Deskripsi wilayah sub-sub DAS yang diteliti disajikan pada tabel 1.

Tabel 1 Deskripsi Sub DAS berdasarkan Lokasi SPAS

\begin{tabular}{|c|c|c|c|c|c|c|}
\hline No. & $\begin{array}{c}\text { Nama sub } \\
\text { DAS }\end{array}$ & Nama DAS & Nama SPAS & Lokasi SPAS & $\begin{array}{c}\text { Letak } \\
\text { Astronomis }\end{array}$ & Luas (ha) \\
\hline 1 & Alang & Alang & Kedungpadas & Wonogiri & $\begin{array}{l}476532,33- \\
488369,18 \mathrm{mT} \\
9103431,58- \\
9112857,84 \mathrm{mU} \\
\end{array}$ & 4555.473 \\
\hline 2 & Padas & Padas & Katelan & Sragen & $\begin{array}{l}497534,31- \\
504693,32 \mathrm{mT} \\
9188085,16- \\
9197978,25 \mathrm{mU}\end{array}$ & 3335.510 \\
\hline 3 & Tapan & Tapan & Sepanjang & Karanganyar & $\begin{array}{l}512143,57- \\
515712,24 \mathrm{mT} \\
9151023,92- \\
9152488,90 \mathrm{mU}\end{array}$ & 300.702 \\
\hline 4 & Wuryantoro & Wuryantoro & Sendang & Wonogiri & $\begin{array}{l}481064,21- \\
486597,74 \mathrm{mT} \\
9128629,34- \\
9134585,28 \mathrm{mU}\end{array}$ & 1777.827 \\
\hline 5 & Keduang & Keduang & Ngadipiro & Wonogiri & $\begin{array}{l}490446,22- \\
526192 \mathrm{mT} \\
9123416,77- \\
9148558,26 \mathrm{mU}\end{array}$ & 42104.739 \\
\hline 6 & Progo Hilir & Progo & Banjar Harjo & KulonProgo & $\begin{array}{l}413863,98- \\
418830,72 \mathrm{mT} \\
91517735,13- \\
914865599 \mathrm{mU}\end{array}$ & 350.650 \\
\hline 7 & Tajum & Serayu & Gumelar & Kebumen & $\begin{array}{l}273328,80- \\
276687,81 \mathrm{mT} \\
9181506,78- \\
9184717,26 \mathrm{mU}\end{array}$ & 1221,204 \\
\hline 8 & Tinggal & Progo Hulu & Gandon & Temanggung & $\begin{array}{l}415505,66 \\
-425039,32 \mathrm{mT} \\
9192879,05- \\
9201757,36 \mathrm{mU} \\
\end{array}$ & 4237.690 \\
\hline 9 & Medono & Serang & Trancap & Wonosobo & $\begin{array}{l}368930,83 \\
-372632,49 \mathrm{mT} \\
9172458,36- \\
9176813,73 \mathrm{mU}\end{array}$ & 873.371 \\
\hline 10 & Sampang & Serayu & Sampang & Banjarnegara & $\begin{array}{l}\text { 357646,66 - } \\
361830,17 \mathrm{mT} \\
9195373,60- \\
9199527,75 \mathrm{mU}\end{array}$ & 781.706 \\
\hline
\end{tabular}




\begin{tabular}{|c|c|c|c|c|c|c|}
\hline 11 & Karangmojo & Opak - Oyo & Karangmojo & Gunungkidul & $\begin{array}{l}464961,78- \\
469766,95 \mathrm{mT} \\
9118489,36- \\
9121737,22 \mathrm{mU}\end{array}$ & 530.596 \\
\hline 12 & $\begin{array}{l}\text { Luk Ulo } \\
\text { Hulu }\end{array}$ & Luk-Ulo & Gunungsari & Kebumen & $\begin{array}{l}346134,09- \\
347940,55 \mathrm{mT} \\
9167497,39- \\
9169387,71 \mathrm{mU}\end{array}$ & 214.656 \\
\hline 13 & Gebang & Wawar & Sawangan & Purworejo & $\begin{array}{l}368440,73- \\
373671,82 \mathrm{mT} \\
9155886,32- \\
9161833,81 \mathrm{mU}\end{array}$ & 1517.873 \\
\hline 14 & Kamal & Serayu & Kamal & Kulonprogo & $\begin{array}{l}403320,07- \\
405780,82 \mathrm{mT} \\
9134959,13- \\
9137857,81 \mathrm{mU}\end{array}$ & 179.005 \\
\hline 15 & $\begin{array}{l}\text { Elo } \\
\text { Blongkeng }\end{array}$ & Progo & Pucungsari & Magelang & $\begin{array}{l}423946,78- \\
428683,42 \mathrm{mT} \\
9178538,72- \\
9179893,65 \mathrm{mU}\end{array}$ & 151.900 \\
\hline
\end{tabular}

Bahan dan alat yang dibutuhkan dalam penelitian ini beserta kegunaannya disajikan pada tabel 2 .

Tabel 2 Bahan dan Alat yang Digunakan dalam Penelitian

\begin{tabular}{|l|l|l|}
\hline No. & \multicolumn{1}{|c|}{ Nama Bahan/Alat } & \multicolumn{1}{c|}{ Kegunaan } \\
\hline 1. & Citra Landsat ETM+ & $\begin{array}{l}\text { Untuk membuat Peta Kerapatan Vegetasi Penutup Lahan } \\
\text { (Analisis Transformasi Indeks vegetasi) }\end{array}$ \\
\hline 2. & Peta Topografi Skala 1:50.000 & Sebagai peta dasar membuat peta lereng, jaringan sungai \\
\hline 3. & Peta Geologi & $\begin{array}{l}\text { Untuk menyadap Informasi geologi (Selanjutnya untuk } \\
\text { analisis Akuifer batuan untuk perkiraan kemampuan } \\
\text { resesi aliran dasar sub DAS) }\end{array}$ \\
\hline 4. & Data SPAS & Untuk pengukuran \& pencatatan data debit aliran sungai \\
\hline 5. & Data AWLR & Untuk pengumpulan data Tinggi Muka Air \\
\hline 6. & Sorfware ArcGIS/ENVI/EXCEL & Penyajian dan Analisis Data Spasial \\
\hline 7. & Seperangkat Komputer & Analisis \& Penulisan Hasil Penelitian \\
\hline
\end{tabular}

\section{Analisis Data}

\section{Analisis Tujuan ke-1: Data Kerapatan Vegetasi Penutup Lahan (NDVI).}

Analisis data indeks vegetasi NDVI dilakukan menggunakan fasilitas menu BandMath pada ENVI 4,0, yaitu dengan menuliskan persamaan matematisnya, di mana selisih pengurangan antara saluran inframerah dekat terhadap saluran merah dibagi oleh hasil penjumlahan dari keduanya. Hasil pengolahan citra NDVI berupa data raster. Untuk proses analisa lebih lanjut, maka citra raster yang diperoleh harus diubah dalam bentuk vektor, melalui AutoVectorize agar nilai atribut yang nantinya digunakan dalam analisis merupakan nilai NDVI asli. Klasifikasi dilakukan melalui menu proses classification ISOCLASS unsupervised classification dan menu edit classregion color and name dimasukkan kelas kerapatan vegetasi.

Nilai NDVI setiap sub DAS diambil nilai rata-rata sebagai nilai NDVI tunggal, kemudian dikorelasikan dengan koefisien 
resesi untuk menganalisis hubungan antara kedua parameter tersebut. Klasifikasi hasil transformasi NDVI disajikan pada tabel 3.

Tabel 3 Klasifikasi Hasil Transformasi NDVI

\begin{tabular}{|l|l|l|}
\hline Kelas & \multicolumn{1}{|c|}{ Nilai NDVI } & \multicolumn{1}{c|}{ Tingkat Kerapatan Vegetasi } \\
\hline 1 & $(-0,8093)-(-0,4349)$ & Tanpa atau sedikit vegetasi \\
\hline 2 & $(-0,4349)-(-0,1654)$ & Vegetasi Jarang \\
\hline 3 & $(-0,1654)-0,1090$ & Vegetasi Sedang \\
\hline 4 & $0,1090-0,3835$ & Vegetasi Rapat \\
\hline 5 & $0,3835-0,6579$ & Vegetasi Sangat Rapat \\
\hline
\end{tabular}

Sumber: Klasifikasi NDVI hasil proses Citra Landsat $7 \mathrm{ETM}^{+}$

Analisis Tujuan ke-2: Koefisien Resesi Baseflow

Faktor yang membedakan kecepatan pelepasan aliran dalam suatu persamaan lengkung resesi baseflow bisanya dinyatakan dalam koefisien resesi (K). Dalam penelitian ini, yang akan dicari adalah koefisien resesi baseflow $\left(\mathrm{K}_{\mathrm{rb}}\right)$, yang ditentukan dengan menggambarkan nilai-nilai Qo terhadap Qt pada selang waktu $t$ satu hari. Nilai Qo dan Qt diambil dari sembarang kurva resesi aliran dasar pada hidrograf aliran, di mana pada penyebaran titik-titik merupakan hasil plot dari nilai Qo dan Qt, kemudian dibuat regresi linier dengan fungsi sebagai berikut:

$$
\begin{gathered}
\mathrm{Qt}=\mathrm{K}_{\mathrm{rb}} \mathrm{Qo} \\
K_{r b}=\frac{Q_{t}}{Q_{0}}
\end{gathered}
$$

di mana: $\quad Q_{t}=$ debit sesudah waktu $t$

$\mathrm{Q}=$ debit permulaan

$\mathrm{K}_{\mathrm{r}}=$ koefisien resesi dari lengkung resesi hidrograf aliran

\section{Analisis Tujuan ke-3: Hubungan NDVI dan Persentase Kerapatan Vegetasi}

Analisis regresi digunakan untuk menunjukkan hubungan antara variabel terikat $y$ dan variabel bebas $x$. Hasil transformasi indeks vegetasi berupa kerapatan vegetasi penutup lahan (nilai NDVI) dipasangkan dengan koefisien resesi. Kerapatan vegetasi penutup lahan dianggap sebagai variabel bebas, sedangkan nilai koefisien resesi sebagai variabel terikat. Dengan demikian, setiap sub DAS sampel akan memiliki satu nilai $y$ dan satu nilai $x$. Pasangan nilai tersebut apabila diplot pada sistem koordinat cartesius akan menunjukkan sebaran dengan pola tertentu. Pola tersebut akan sangat penting dalam penentuan jenis persamaan regresi yang akan dibuat, apakah linier atau cenderung membentuk kurva..

\section{PEMBAHASAN}

Karakteristik Kerapatan Vegetasi dari transformasi indeks vegetasi NDVI (Normalized Difference Vegetation Index)

\section{Transformasi Indeks Vegetasi NDVI}

Hasil perhitungan transformasi indeks vegetasi NDVI masing-masing subDAS disajikan pada gambar 2. Nilai NDVI negatif menunjukkan kerapatan vegetasi rendah meliputi subDAS Alang, Padas, Tapan, Wuryantoro Keduang, Karangmojo, dan Sawangan. Sedangkan nilai NDVI positif menunjukkan kerapatan vegetasi sedang sampai rapat meliputi subDAS Progo hilir, gumelar, Medono, Sampang, Luk Ulo hulu, Kamal, dan Elo-Blongkeng. 


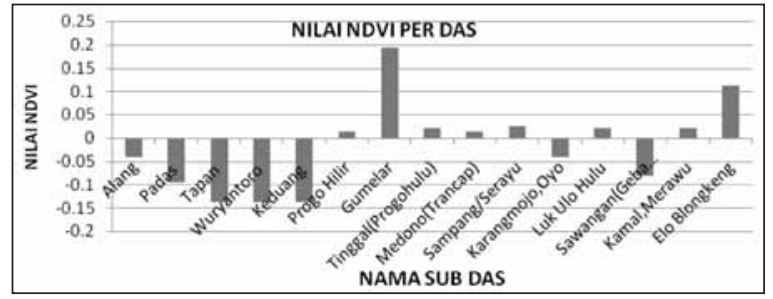

Gambar 2. Diagram Batang Nilai NDVI per subDAS

Persebaran nilai NDVI berdasarkan klasifikasi kelas kerapatan vegetasi menunjukkan bahwa sebagian besar subDAS berada pada klasifikasi kerapatan vegetasi sedang, di mana keseluruhan sub DAS penelitian merupakan wilayah-wilayah program konservasi tanah dan air dari BPDAS Serayu Opak Progo (BPDAS SOP) dan Balai Penelitian Kehutanan Surakarta Departemen Kehutanan. Dengan demikian kondisi kerapatan vegetasi penutup lahan di wilayah-wilayah tersebut kerapatan vegetasi termasuk kategori relatif baik.

\section{Hubungan NDVI dan Persentase Kerapatan Vegetasi}

Nilai NDVI yang mempresentasikan kerapatan vegetasi subDAS perlu dilakukan untuk nilai transformasi NDVI rata-rata dari hutan primer, hutan sekunder dan ladang, kemudian dilakukan uji statistik dengan liputan vegetasi untuk menggambarkan karakteristik kerapatan vegetasi di setiap subDAS penelitian. Liputan vegetasi yang diperoleh merupakan hasil uji statistik dari data pengukuran kerapatan tajuk dari beberapa penelitian, selanjutnya dilakukan uji korelasi antara nilai NDVI dengan persentase kerapatan tajuk yang dianggap merefresentasikan hubungan determinasi antara kerapatan tajuk dengan nilai NDVI.

Hasil transformasi NDVI untuk sub DAS penelitian (peta terlampir) menunjukkan terdapatnya korelasi antara nilai NDVI dan kerapatan vegetasi dalam bentuk persamaan matematis. Dalam hal ini, nilai kerapatan vegetasi dianggap sebagai variabel $x$, sedangkan nilai NDVI yang besarnya tergantung dari nilai kerapatan vegetasi, dianggap sebagai variabel y. Pasangan nilai sampel menghasilkan distribusi titiktitik data yang membentuk pola linier yang disajikan dalam gambar 3 .

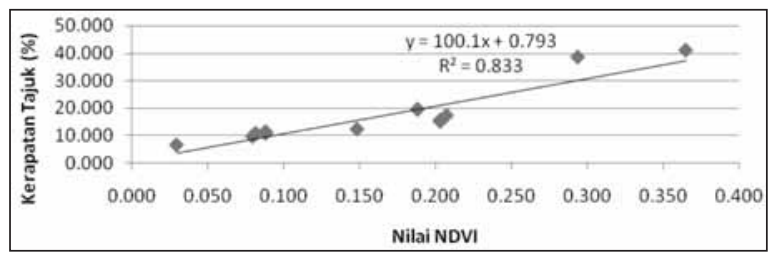

Gambar 3 Hubungan NDVI dengan Kerapatan Tajuk

Kerapatan vegetasi dan NDVI memiliki hubungan yang searah, dengan kata lain pada nilai kerapatan vegetasi yang semakin tinggi diperoleh dengan nilai NDVI yang semakin tinggi dan sebaliknya, bila kerapatan vegetasi rendah akan diperoleh nilai NDVI yang rendah. Hal ini dapat diamati dengan jelas dari distribusi titik data pada diagram pencar. Hubungan yang kuat antara NDVI dan kerapatan vegetasi, seperti dilihat dari nilai koefisien determinasi yang mendekati 1. Akan tetapi, sistem DAS yang kompleks, hubungan yang kuat ini belum dapat dijadikan fakta tunggal bahwa hanya kerapatan vegetasi semata-mata yang berpengaruh kuat terhadap nilai NDVI.

\section{Karakteristik Resesi Aliran Dasar Pembuatan Lengkung Resesi Aliran Dasar}

Hasil persamaan liku kalibrasi dan koefisien determinasi $\left(\mathrm{R}^{2}\right)$ dari subDAS penelitian disajikan dalam tabel 4. Persamaan liku kalibrasi untuk seluruh subDAS penelitian memiliki koefisien determinasi $\left(\mathrm{R}^{2}\right)$ tinggi antara $0.60 \mathrm{~s} / \mathrm{d}$ 0.90. Hal ini menunjukkan hubungan yang relatif kuat, yang berarti bahwa variasi debit (Q) dapat dijelaskan dengan tinggi muka air $(\mathrm{H})$ sebesar 60 \% s/d 90. Sehingga persamaan regresi (Q) atas $(\mathrm{H})$ dapat dipakai untuk menduga $\mathrm{Q}$ atas dasar $(\mathrm{H})$. 
Tabel 4. Persamaan Lengkung Aliran dan Koefisien Determinasi Hidrograf

\begin{tabular}{|l|l|l|l|l|}
\hline No. & \multicolumn{1}{|c|}{ Nama sub DAS } & \multicolumn{1}{|c|}{ Luas (ha) } & \multicolumn{1}{c|}{ Persamaan Liku Kalibrasi } & \multicolumn{1}{c|}{$\mathbf{R}^{\mathbf{2}}$} \\
\hline 1 & Alang & 4555.473 & $\mathrm{Q}=19,49(\mathrm{H}-0,0226)^{0.78}$ & 0.889 \\
\hline 2 & Padas & 3335.510 & $\mathrm{Q}=4,57(\mathrm{H}-0,263)^{0.6}$ & 0.789 \\
\hline 3 & Tapan & 300.702 & $\mathrm{Q}=0.963(\mathrm{H}-0.01)^{1.31}$ & 0.816 \\
\hline 4 & Wuryantoro & 1777.827 & $\mathrm{Q}=0.375(\mathrm{H}-0.3)^{0,0.32}$ & 0.562 \\
\hline 5 & Keduang & 42104.739 & $\mathrm{Q}=7.85(\mathrm{H}-0,275)^{0.382}$ & 0.804 \\
\hline 6 & Progo Hilir & 350.650 & $\mathrm{Q}=0,91(\mathrm{H}-0,0275)^{0.23}$ & 0.824 \\
\hline 7 & Gumelar & 1221.204 & $\mathrm{Q}=0,57(\mathrm{H}+0,205)^{0.84}$ & 0.842 \\
\hline 8 & Tinggal(Progohulu) & 4237.690 & $\mathrm{Q}=0.93(\mathrm{H}+1.66)^{0.86}$ & 0.901 \\
\hline 9 & Medono(Trancap) & 873.371 & $\mathrm{Q}=1,11(\mathrm{H}-0,168)^{0.63}$ & 0.820 \\
\hline 10 & Sampang/Serayu & 781.706 & $\mathrm{Q}=1,64(\mathrm{H}-0,39)^{0.1}$ & 0.612 \\
\hline 11 & Karangmojo,Oyo & 530.596 & $\mathrm{Q}=0.96(\mathrm{H}+1.66)^{0.93}$ & 0.612 \\
\hline 12 & Luk Ulo Hulu & 214.656 & $\mathrm{Q}=10,82(\mathrm{H}-0,066)^{2,15}$ & 0.755 \\
\hline 13 & Sawangan(Gebang) & 1517.873 & $\mathrm{Q}=2,08(\mathrm{H}-0.049)^{0.24}$ & 0.871 \\
\hline 14 & Kamal,Merawu & 179.005 & $\mathrm{Q}=2,80(\mathrm{H}-0,56)^{0.33}$ & 0.795 \\
\hline 15 & Elo Blongkeng & 151.900 & $\mathrm{Q}=0,88(\mathrm{H}-0.003)^{0,077}$ & 0.871 \\
\hline
\end{tabular}

Sumber : Analisis Data Sekunder BPK Surakarta \& BPDAS SOP Yogyakarta, 2006

\section{Penentuan Koefisien Resesi Aliran Dasar}

Data observasi aliran yang digunakan ada hidrograf aliran pada masing-masing subDAS. Data tersebut dikonversi menjadi data hubungan debit terhadap waktu, atau hidrograf menggunakan persamaan lengkung terbaik pada masing-masing sub DAS. Kemudian hidrograf tersebut dilakukan pemisahan aliran untuk menentukan lengkung resesi aliran dasar. Dari pemisahan tersebut diperoleh titik belok (infelection point) merupakan awal dari lengkung resesi aliran dasar. Pemisahan ini untuk menentukan titik awal lengkung resesi pada masing-masing sub DAS.

Untuk menghitung koefisien resesi, dilakukan dengan mengambil nilai $Q_{t}$ setelah 1 jam. Nilai $K_{r b}$ ditentukan dengan menggambarkan nilai-nilai $Q_{0}$ terhadap $Q_{t}$ dengan selang waktu $t$, satu hari. Nilai-nilai $\mathrm{Q}_{0}$ dan $\mathrm{Q}_{\mathrm{t}}$ diambil dari sembarang kurva resesi aliran dasar pada hidrograf aliran, di mana pada penyebaran titik-titik hasil plot dari nilai $Q_{0}$ dan $Q_{r}$, kemudian dibuat regresi linier dengan fungsi $Q_{\mathrm{t}}=\mathrm{K}_{\mathrm{rb}} \mathrm{Q}_{0}$ dan $\mathrm{K}_{\mathrm{rb}}=\mathrm{Q}_{\mathrm{t}} / \mathrm{Q}_{0}$.

Sifat hidrologis dari fungsi resesi baseflow yaitu bahwa nilai koefisien resesi semakin mendekati satu, maka lengkung resesi baseflow semakin landai, dan sebaliknya semakin kecil nilai koefisien resesi, maka lengkung resesi baseflow semakin curam. Hasil perhitungan koefisien resesi untuk keseluruhan subDAS relatif landai di atas 0,6 seperi yang disajikan pada Gambar 4 .

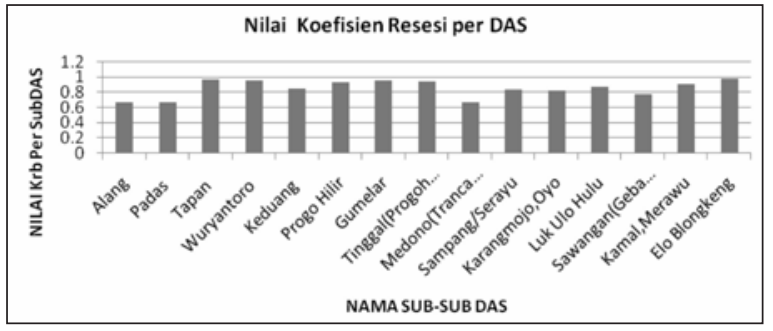

Gambar 4. Diagram Batang Nilai Koefisien Resesi (Krb) per SubDAS Penelitian

\section{Pengaruh Kerapatan Penutupan Lahan terhadap Karakteristik Resesi Hidrograf}

Hubunganantara nilai NDVI) dankoefisien resesi disajikan dalam tabel 5 . Nilai NDVI $(0,030$ $\mathrm{s} / \mathrm{d} 0,365)$ dengan persentase kerapatan vegetasi (6,835 s/d 41,147\%), dikorelasikan dengan koefisien resesi $(\mathrm{Krb})$ yang berkisar antara 0,661 s/d 0,980, di mana hampir semua subDAS penelitian memiliki kondisi relatif landai. Hal ini terkait dengan kondisi formasi geologi sub DAS penelitian yang memiliki kemampuan menampung, menyimpan, dan meloloskan air relatif baik. Deskripsi formasi geologi disajikan pada tabel 6. 
Tabel 5 Uji Korelasi NDVI Penutup Lahan dengan Koefisien Resesi di Sub-sub DAS yang Diteliti

\begin{tabular}{|l|l|l|l|}
\hline No. & \multicolumn{1}{|c|}{ Nama DAS } & (NDVI) Kerapatan Vegetasi & Koefisien Resesi Krb \\
\hline 1 & Alang & 0.088 & 0.669 \\
\hline 2 & Padas & 0.149 & 0.661 \\
\hline 3 & Tapan & 0.082 & 0.960 \\
\hline 4 & Wuryantoro & 0.082 & 0.953 \\
\hline 5 & Keduang & 0.080 & 0.841 \\
\hline 6 & Progo Hilir & 0.188 & 0.929 \\
\hline 7 & Gumelar & 0.365 & 0.955 \\
\hline 8 & Tinggal(Progohulu) & 0.203 & 0.944 \\
\hline 9 & Medono(Trancap) & 0.188 & 0.664 \\
\hline 10 & Sampang/Serayu & 0.208 & 0.832 \\
\hline 11 & Karangmojo,Oyo & 0.088 & 0.821 \\
\hline 12 & Luk Ulo Hulu & 0.203 & 0.873 \\
\hline 13 & Sawangan(Gebang) & 0.030 & 0.768 \\
\hline 14 & Kamal,Merawu & 0.203 & 0.908 \\
\hline 15 & Elo Blongkeng & 0.294 & 0.980 \\
\hline
\end{tabular}

Sumber : Hasil Analisis Data sekunder BPK Surakarta \& BPDAS SOP Yogyakarta, 2006.

Tabel 6. Deskripsi Formasi Geologi di SubDAS Penelitian

\begin{tabular}{|c|c|c|c|c|c|c|c|}
\hline No & Nama DAS & Simbol & $\begin{array}{l}\text { Nama } \\
\text { Lembar }\end{array}$ & $\begin{array}{c}\text { No. } \\
\text { Lembar }\end{array}$ & $\begin{array}{c}\text { Nama Batuan } \\
\text { Induk }\end{array}$ & Klasifikasi Litologi & $\begin{array}{l}\text { Periode } \\
\text { Batuan }\end{array}$ \\
\hline 1 & Alang & Qlla & Ponorogo & 1508 & Lahar Lawu & $\begin{array}{l}\text { Extrusive: } \\
\text { intermediate: polymict }\end{array}$ & Kuarter \\
\hline 2 & Padas & Tmk & Salatiga & 1408 & Formasi Kerek & & Neogen \\
\hline 3 & Tapan & Qlla & Ponorogo & 1508 & Lahar Lawu & $\begin{array}{l}\text { Extrusive: } \\
\text { intermediate: polymict }\end{array}$ & Kuarter \\
\hline 4 & Wuryantoro & Tomm3 & Surakarta & 1408 & $\begin{array}{l}\text { Formasi } \\
\text { Mandalika }\end{array}$ & Formasi Mandalika & Paleogen \\
\hline 5 & Keduang & Qlla & Ponorogo & 1508 & Lahar Lawu & $\begin{array}{l}\text { Extrusive: } \\
\text { intermediate: polymict }\end{array}$ & Kuarter \\
\hline 6 & Progo Hilir & Tomk & Yogyakarta & 1407 & $\begin{array}{l}\text { Formasi } \\
\text { Kebobutak }\end{array}$ & $\begin{array}{l}\text { Sediment: clastic: } \\
\text { medium: flysch }\end{array}$ & Paleogen \\
\hline 7 & Serayu & Qjmf & Banjarnegara & 1408 & $\begin{array}{l}\text { Batuan } \\
\text { Gunungapi } \\
\text { Jembangan }\end{array}$ & $\begin{array}{l}\text { Extrusive: } \\
\text { intermediate: lava }\end{array}$ & Kuarter \\
\hline 8 & Progo Hulu & QTp1 & Magelang & 1408 & $\begin{array}{l}\text { Formasi } \\
\text { Penyatan }\end{array}$ & $\begin{array}{l}\text { Sediment: clastic: } \\
\text { medium: flysch }\end{array}$ & Neogen \\
\hline 9 & $\begin{array}{l}\text { Trancap } \\
\text { Medono }\end{array}$ & Tmw3 & Kebumen & 1401 & $\begin{array}{l}\text { Formas } \\
\text { Waturanda }\end{array}$ & $\begin{array}{l}\text { Sediment: clastic: } \\
\text { medium: sandstone }\end{array}$ & Neogen \\
\hline 10 & Tapan & Qlla & Ponorogo & 1508 & Lahar Lawu & $\begin{array}{l}\text { Extrusive: } \\
\text { intermediate: polymict }\end{array}$ & Kuarter \\
\hline 11 & Karangmojo & Tomk & Yogyakarta & 1407 & $\begin{array}{l}\text { Formasi } \\
\text { Kebobutak }\end{array}$ & $\begin{array}{l}\text { Sediment: clastic: } \\
\text { medium: flysch }\end{array}$ & Paleogen \\
\hline 12 & Luk Ulo Hulu & Tomt1 & Banjarnegara & 1408 & $\begin{array}{l}\text { Formasi } \\
\text { Totogan } \\
\end{array}$ & $\begin{array}{l}\text { Extrusive: } \\
\text { intermediate: polymict }\end{array}$ & Paleogen \\
\hline 13 & Sawangan & Tpp1 & Kebumen & 1401 & $\begin{array}{l}\text { Formasi } \\
\text { Peniron }\end{array}$ & $\begin{array}{l}\text { Sediment: clastic: } \\
\text { coarse: breccia }\end{array}$ & Neogen \\
\hline 14 & Kamal & Tomk & Yogyakarta & 1407 & $\begin{array}{l}\text { Formasi } \\
\text { Kebobutak }\end{array}$ & $\begin{array}{l}\text { Sediment: clastic: } \\
\text { medium: flysch }\end{array}$ & Paleogen \\
\hline 15 & Eloblokeng & Qvu3 & Salatiga & 1408 & $\begin{array}{l}\text { Batuan } \\
\text { Gunungapi Tak } \\
\text { Terpisahkan }\end{array}$ & $\begin{array}{l}\text { Extrusive: } \\
\text { intermediate: } \\
\text { polymict }\end{array}$ & Kuarter \\
\hline
\end{tabular}

Sumber : Peta Geologi Jawa Tengah dan DIY 
Hubungan antara kedua variabel menghasilkan persamaan matematis dan distribusi titik-titik data yang membentuk pola linier disajikan dalam gambar 5 .

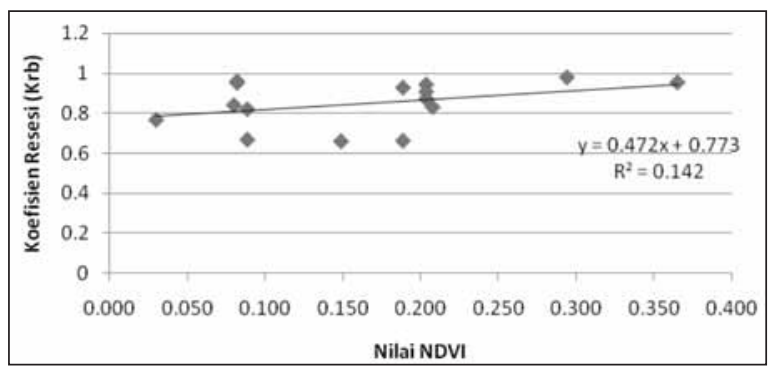

Gambar 5. Hubungan NDVI dengan Koefisien Resesi

Hasil uji statistik NDVI dan koefisien resesi menunjukkan $\mathrm{R}^{2}=0,1427, \mathrm{~F}=2.17$ tidak berpengaruh nyata pada taraf signifikan $1 \%$ sebesar 0.1646. Analisis korelasi antara NDVI dan koefisien resesi berkorelasi sangat lemah sebesar 0,077. Parameter kerapatan vegetasi NDVI sangat lemah untuk mengontrol keberadaan aliran-aliran rendah. Hal ini dikarenakan besarnya simpanan (storage) airtanah tergantung pada besarnya air yang mencapaiakuifer.Setelah sumbanganair pada akuifer terhenti, maka air yang tertampung di akuifer akan mengalami pengatusan yang besarnya tergantung kondisi akuifer tersebut. Gerakan air pada akuifer disebabkan oleh gaya gravitasi, kecepatan, dan jumlahnya terutama dipengaruhi oleh karakteristik batuan. Karakteristik batuan mempengaruhi pergerakan airtanah, diketahui dari daya hantar hidrolik batuan tersebut.

Hubungan keeratann antara kerapatan vegetasi (NDVI) dan koefisien resesi relatif lemah, namun secara substansial hubungan keeratan ini masih berkontribusi untuk proses-proses aliran di sistem hidrologi suatu DAS dalan kurun waktu yang lama. Sebagai salah satu komponen dalam sistem hidrologi, penutup lahan vegetasi masih tetap akan mempengaruhi hasil aliran keluar dan perlu diperhitungkan dalam pengelolaan suatu DAS.

\section{SIMPULAN}

Indeks vegetasi NDVI sebagai refresentasi kerapatan vegetasi penutup lahan memiliki hubungan yang searah. Semakin tinggi nilai NDVI, maka kerapatan vegetasi penutup lahan semakin rapat, dan sebaliknya. Faktor vegetasi dalam sistem DAS bukan faktor tunggal yang mempengaruhi hubungan tersebut. Akan tetapi, vegetasi juga berkontribusi salam sistem pengelolaan DAS yang berimbang dan ramah lingkungan. Persamaan liku kalibrasi untuk keseluruhan subDAS yang memiliki koefisien determinasi yang relatif optimal. Koefisien resesi sebagai refresentasi karakteristik resesi aliran dasar untuk sebagian besar sub DAS penelitian berada pada kisaran antara 0,661 s/d 0,980, yaitu lengkung resesi berbentuk landai. Hasil ini menunjukkan bahwa formasi akuifer di sub DAS memiliki kemampuan menampung, menyimpan dan meloloskan air relatif baik. Korelasi antara indeks vegetasi NDVI dan koefisien resesi menunjukkan hubungan yang sangat lemah, dimana parameter kerapatan vegetasi (indeks vegetasi NDVI) sangat lemah untuk mengontrol keberadaan aliran-aliran rendah. Karakteristik aliran dasar sungai merupakan kombinasi yang bersifat spesifik antara faktor morfometri DAS, kapasitas infiltrasi tanah, jenis batuan serta penutupan vegetasi, iklim, dan topografi.

Kemudian Transformasi indeks vegetasi melalui teknik penginderaan jauh dan sistem informasi geografi, alangkah baiknya perlu dilakukan dalam pemodelan dengan seri waktu data yang akurat dan panjang, sehingga mampu merepresentasikan hubungan meteorologi dan hidrogeologis secara komprehensif. Perlunya analisis komprehensif karakteristik hidrogeologis aliran dasar, terutama hasil spesifik, permeabilitas, dan kesarangan dalam seri waktu yang panjang sehingga lebih merepresentasi keberlanjutan aliran dasar sungai. 
JURNAL TEKRNOSAINS | VOL 2, NO. 2, JUNI 2013 ; 71-92
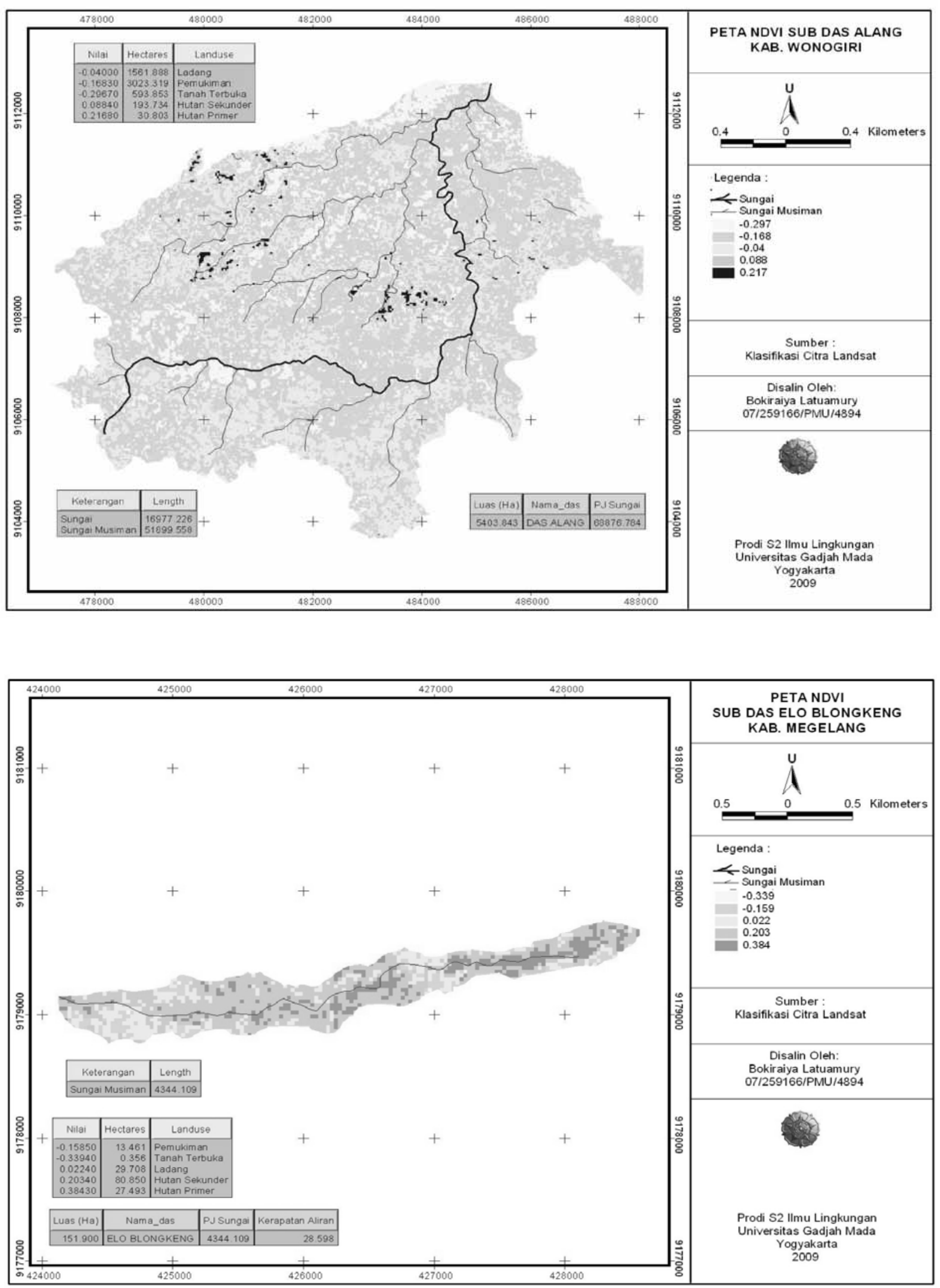
BOKIRAIYA LATUAMURY, TOTOK GUNAWAN, SLAMET SUPRAYOGI $*$ HUBUNGAN ANTARA INDEKS VEGETASI NDVI (NORMALIZED DIFFERENCE VEGETATION INDEX) ...
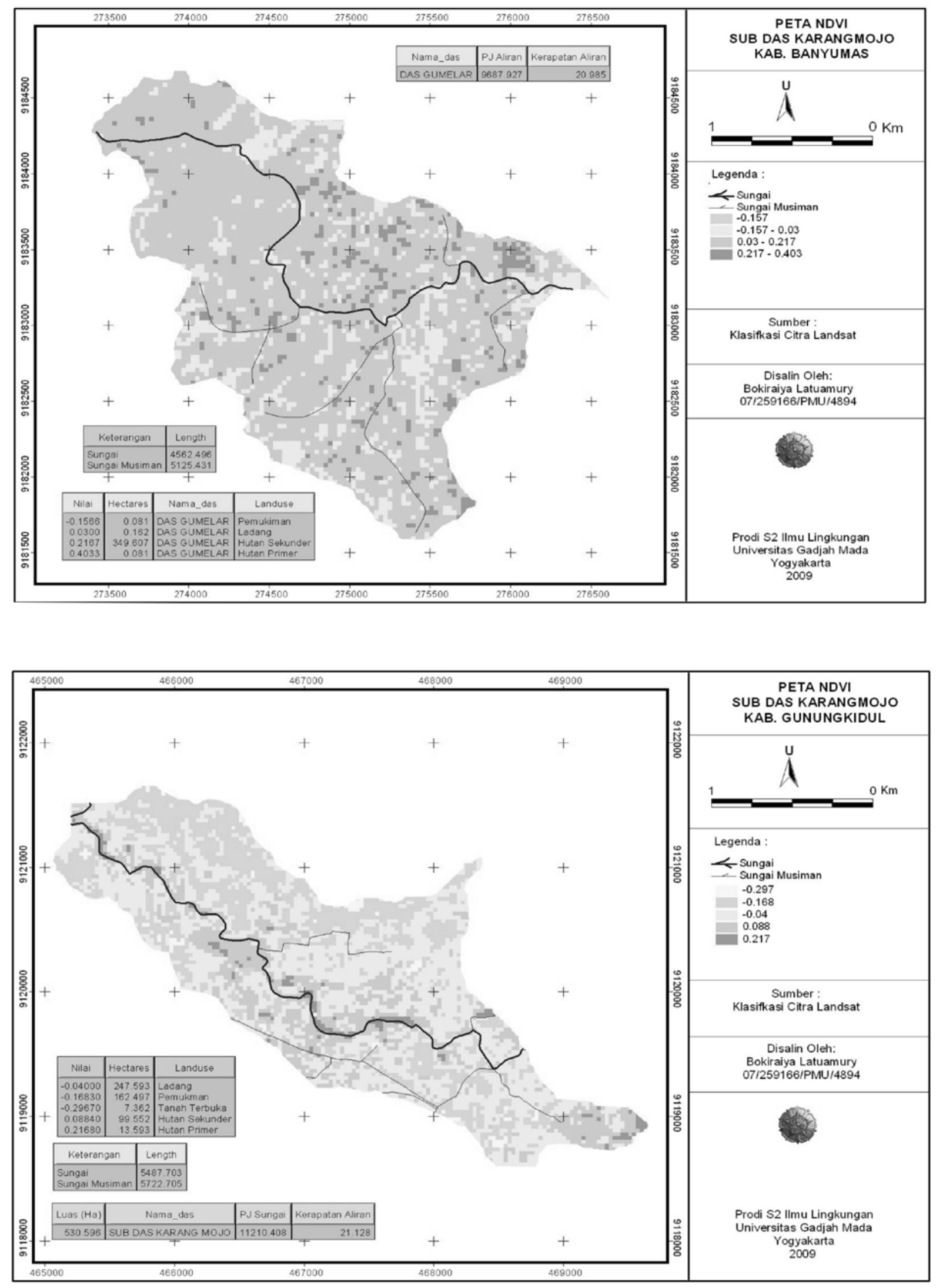
JURNAL TEKRNOSAINS | VOL 2, NO. 2, JUNI 2013 ; 71-92
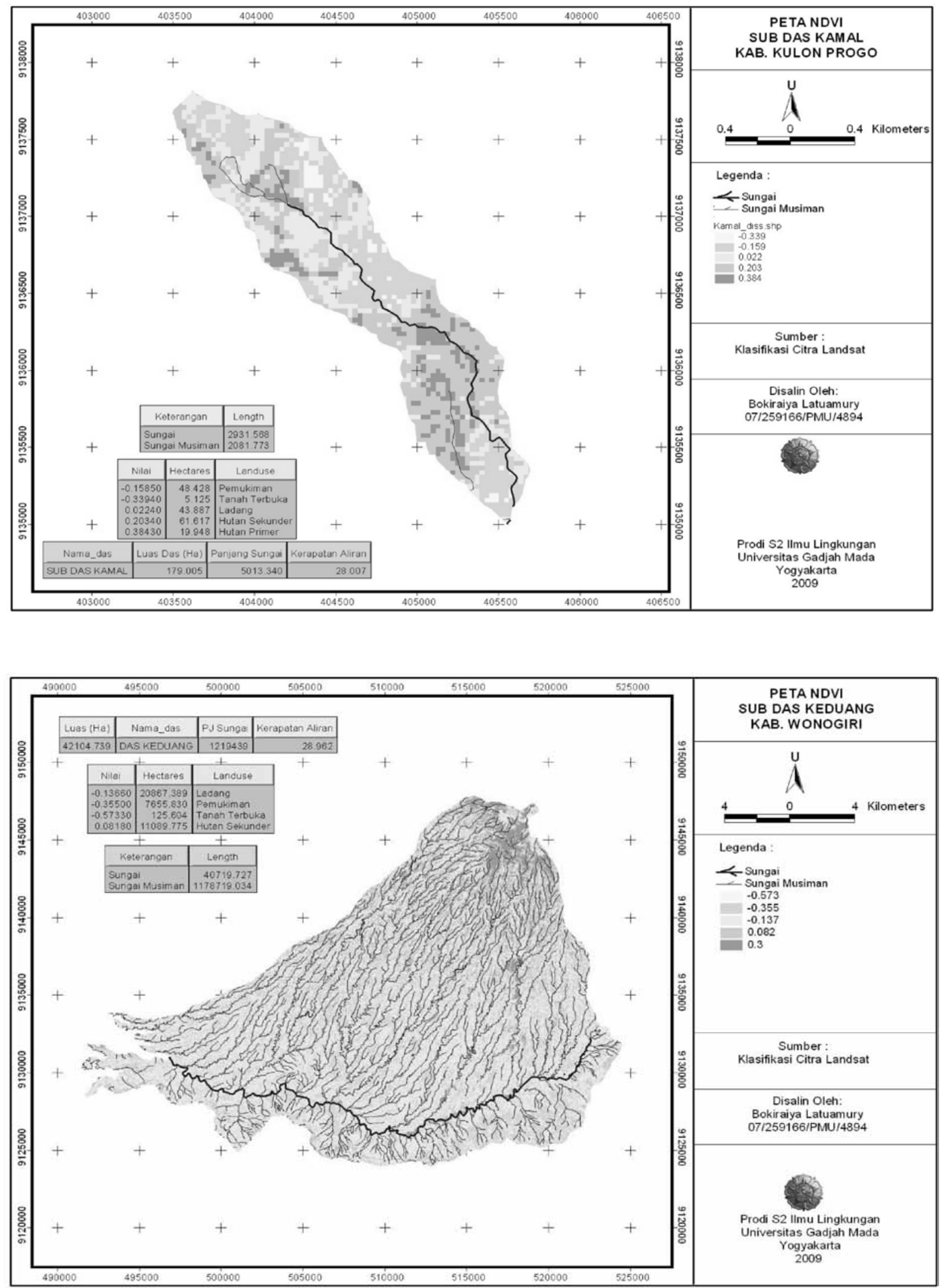
BOKIRAIYA LATUAMURY, TOTOK GUNAWAN, SLAMET SUPRAYOGI $*$ HUBUNGAN ANTARA INDEKS VEGETASI NDVI (NORMALIZED DIFFERENCE VEGETATION INDEX) ...
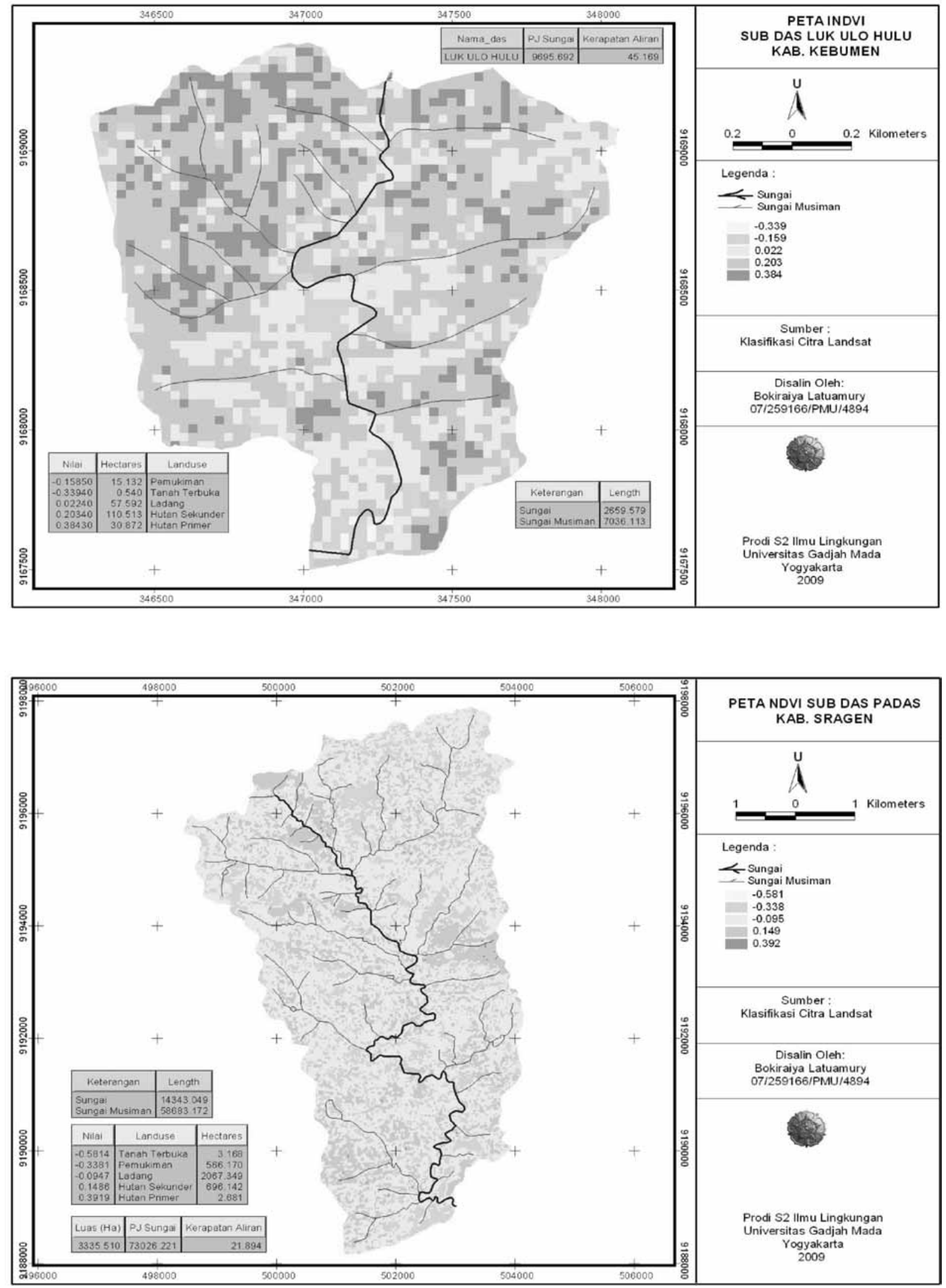
JURNAL च医RNOSAINS | VOL 2, NO. 2, JUNI $2013 ;$ 71-92
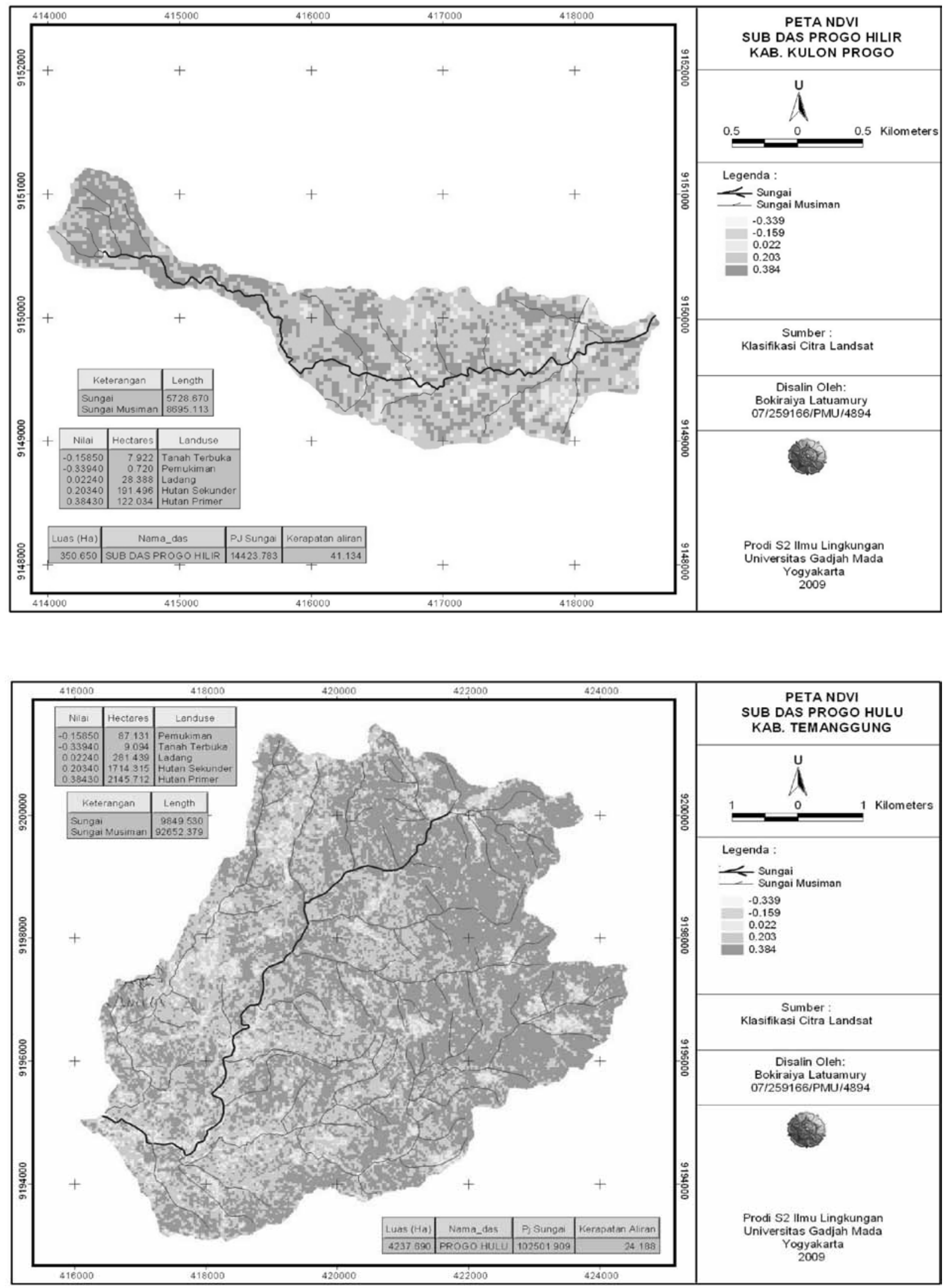
BOKIRAIYA LATUAMURY, TOTOK GUNAWAN, SLAMET SUPRAYOGI $*$ HUBUNGAN ANTARA INDEKS VEGETASI NDVI (NORMALIZED DIFFERENCE VEGETATION INDEX) ...
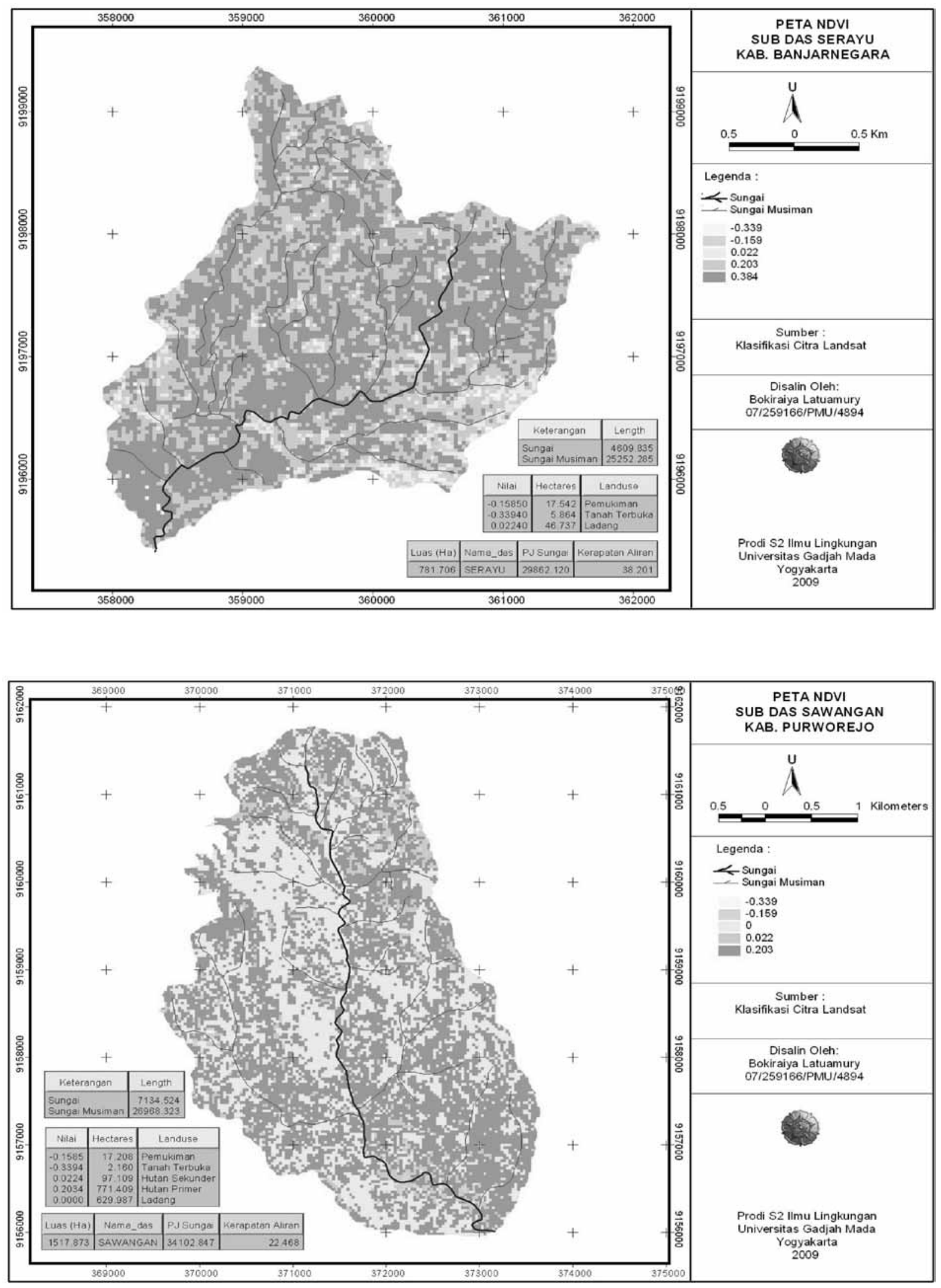
JURNAL TEKRNOSAINS | VOL 2, NO. 2, JUNI 2013 ; 71-92
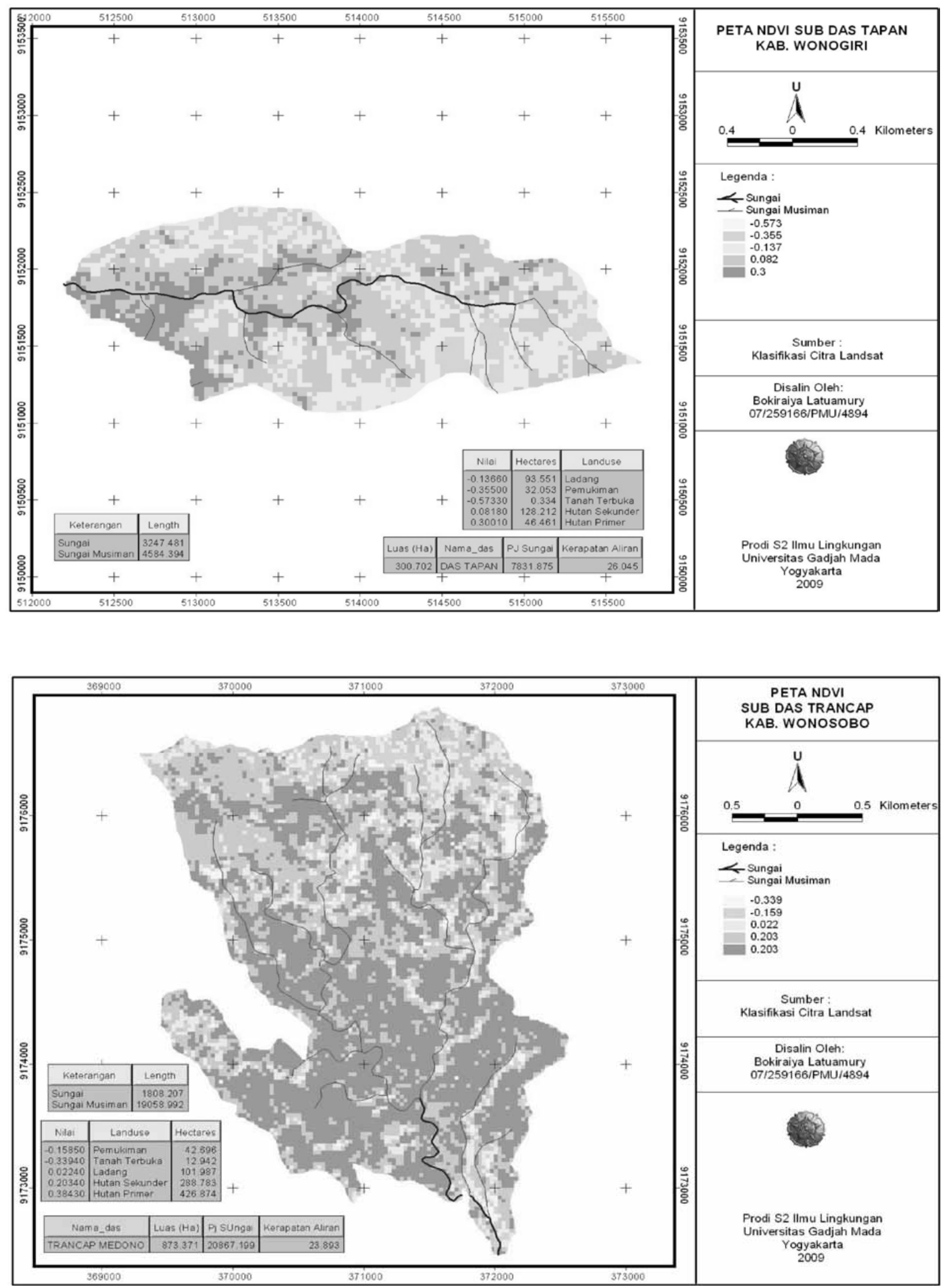


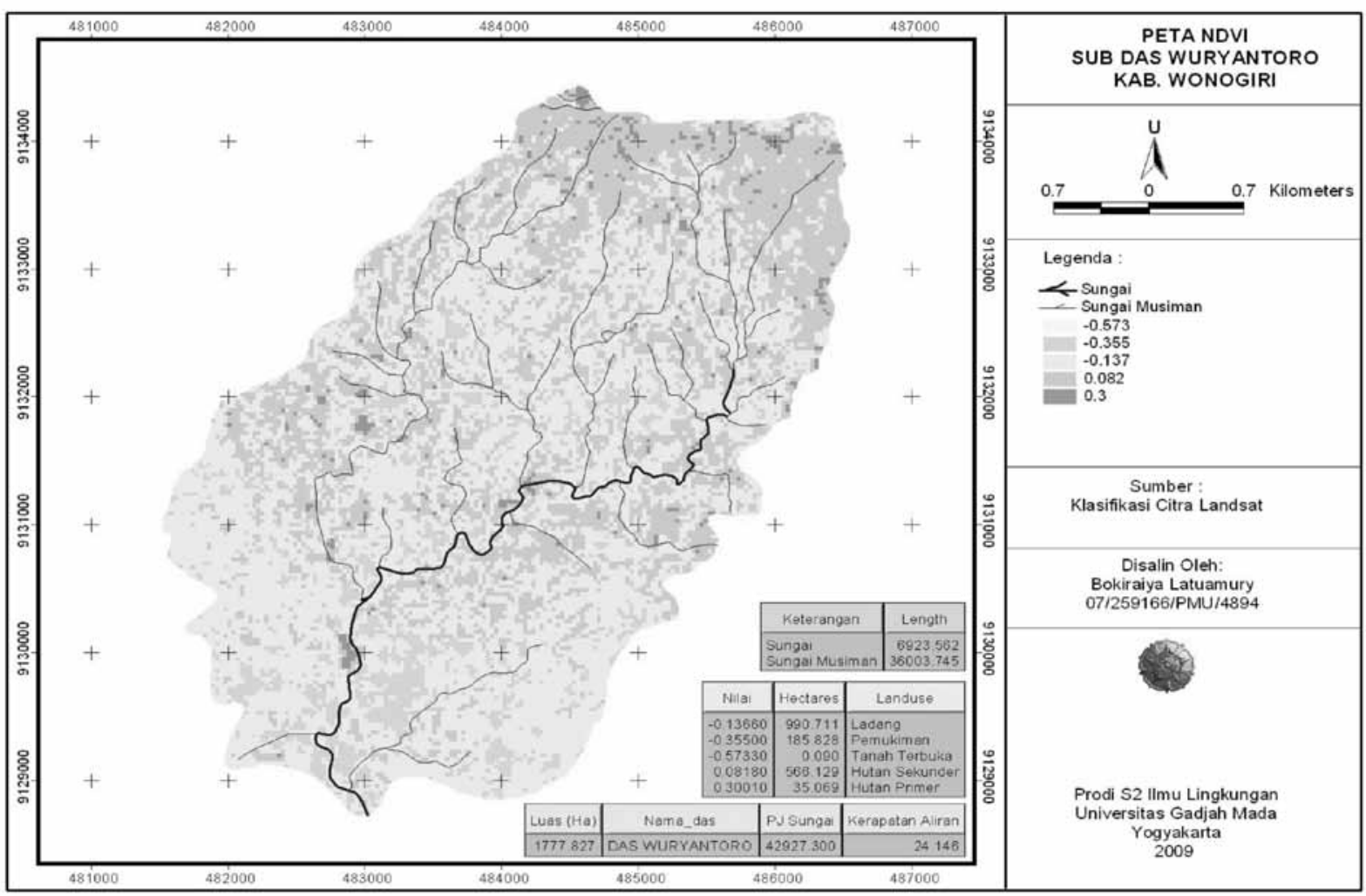

DAFTAR PUSTAKA

Asdak, C, 1995, Hidrologi dan Pengelolaan Daerah Aliran Sungai, Gadjah Mada University Press, Cetakan Pertama, Yogyakarta.

Ayers, H.D. and Ding, J.Y,H., 1967, Effects of surficial geology on streamflow distribution in southern Ontario. Can. J. Earth Sci., 4(2): 187-197.

Bako, M.D. and Owoade, A., 1988, Field application of a numerical method for the derivation of baseflow recession constant. Hydrol. Processes, 2: 331-336.

Barnes, B.S., 1939, The structure of dischargerecession curves. Trans. Am, Geophys: Union, 20: 721-725.

Bates, B.C. and Davies, P.K., 1988, Effect of baseflow separation procedures on surface runoff models, J:Hydrol., 103: 309-322.
Curran, J.C., 1990, Low flow estimation based on river recession rate. J. Inst. Water Environ. Man., 4(4): 350-355.

Danoedoro,P, 2004, Informasi Penggunaan Lahan Multidimensional: Menuјu Sistem Klasifikasi Penggunaan Lahan Multiguna untuk Perencanaan Wilayah dan Pemodelan Lingkungan. Sains Informasi Geografis: Dari perolehan dan Analisis Citra Hingga Pemetaan dan Pemodelan Spasial, Fakultas Geografi, Universitas Gadjah Mada, Yogyakarta.

De Vries,J.J, 1975, Groundwater Hidroulics, Communication of Earth Sciences, Free Reformed University, Amsterdam.

Hall, F.R., 1968, Base flow recessions--a review, Water Resour, Res., 4(5): 973983. 
Hardison, C.H. and Moss, M.E., 1972, Accuracy of low-flow characteristics estimated by correlation of baseflow measurements, US Geol, Surv, Water Supply Pap, 1542-B.

Scultz,E.F, 1974, Problem in Applied Hydrology, Water Resources Publication Foat Collins, Cororado,USA.

Sri Harto, 1993, Analisis Hidrologi, Gramedia. Jakarta.

Tallaksen, L.M.,1987, Vurderingavulikemetoder for $\sim$ kvantifisere magasineringsevnen $i$ et nedborfelt, M.Sc, Thesis, Dep. Geogr., University Oslo. 1989, Analysis of time variability in recessions, IAHS Publ., 187: 85-96.
1991, Recession rate and variability with special emphasis upon the influence of evapotranspiration. Dr. Scient. Thesis, Univ. Oslo, Rapp. Hydrol, 25.

Vogel, R.M, and Krotl, C.N., 1991, Estimation of baseflow recession constants (Abstract). In: D.S. Bowles and P.E. O'Connell (Editors), Recent Advances in the Modeling of Hydrologic Systems. Proc. NATO

and Kroll, C.N., 1992, Regional geohydrologic-geomorphic relationships for the estimation of low flow statistics. Water Resour. Res., 28(9): 2451-2458. 